\title{
Fournierova gangréna
}

\author{
MUDr. Miroslav Šuráň, MUDr. Jana Jarošincová, MUDr. Jan Milota \\ Urologické oddělení, Městská nemocnice v Litoměřicích
}

Fournierova gangréna je velmi závažná nekrotizující fasciitida zevního genitálu a perianální oblasti. Postihuje většinou oslabené jedince se sníženou imunitou a pacienty se závažnými komorbiditami. Léčba spočívá v radikálním chirurgickém odstranění nekróz, terapii širokospektrými antibiotiky, derivaci moči a intenzivní péči. Důležité je její rychlé zahájení. Autoři popisují kazuistiku s nepř́znivým klinickým průběhem.

Klíčová slova: Fournierova gangréna, nekrotizující fascitida, terapie, bakterie.

\section{Fournier's gangrene}

Fournier's gangrene is a very serious necrotizing fasciitis of external genitals and perianal area. It affects mostly weakened immunosuppressed patients and patients with comorbidities. As a treatment there is used radical surgical removal of necrosis, treatment with broad-spectrum antibiotics, drainage and intensive care. It is important a very fast start. Authors describe a clinical case report.

Key words: Fournier's gangrene, necrotizing fasciitis, therapy, bacteria.

\section{Úvod}

Fournierova gangréna (FG) je vzácné, ale mnohdy fulminantně probíhající a život ohrožující onemocnění. Patří k nejzávažnějším stavům v urologii vůbec, mortalita dosahuje podle metaanalýzy 16\% (1), obvykle se uvádí 20-50\%, podle některých zdrojů více než $80 \%$ a nejeví rozdíly mezi pohlavími (2-4).

Jedná se o polymikrobiální infekci, primárně mužského genitálu, vedoucí k fasciitidě a gangréně měkkých tkání šourku, penisu, př́padně perinea a perianální oblasti, obvykle bez postižení varlat. Asi ve $30 \%$ prípadů bývá postižena i kưže penisu, hlavně u diabetiků s fimózou II.-III. st. Nezřídka se Ize s touto infekční komplikací setkat i u žen vyššího věku či dokonce gravidních $(5,6)$. Výjimečně je FG popsána i u dětí (7).

I když byla popsána již v roku 1764 lékařem Bauriennem, pojmenována je po francouzském profesorovi a predním evropském dermatologovi a venerologovi Jeanu Alfredu Fournierovi (1832-1914). Ten ji popsal jako nemoc s prudkým začátkem, rychle progredující gangrénou neznámého původu postihující predtím zdravé, mladé muže a vedoucí k destrukci genitálu (8).

$\checkmark$ dnešní době se s onemocněním setkáváme častěji u osob vyššího věku, při oslabení organismu imunodeficiencí, diabetem, alkoholismem, nikotinismem, malnutricí či nádorovým onemocněním. Může vzniknout také jako důsledek traumatu, urologického, gynekologického či kolorektálního onemocnění nebo chirurgického výkonu s tímto onemocněním spojeným, zvláště u rizikových pacientů $(9,10)$.

Původcem infekce je u FG většinou smíšená aerobní a anaerobní flóra, následována $E$. coli (46,6\%) a Streptococcus (36,8\%), která se šiří z oblasti urogenitálního traktu, anorekta či kůže zevního genitálu. Dalšími patogeny jsou: Bacteroides, Enterobacter, Staphylococcus, Enterococcus, Pseudomonas, Corynebacterium, a Klebsiella pneumoniae (11). Původcem ovšem mohou být vzácně i kvasinkové mikroorganismy (12).

\section{Diagnostický a léčebný postup u FG}

Prvním pozorovatelným příznakem onemocnění je většinou lividní skvrna v oblasti brány vstupu infekce, s otokem a zarudnutím v okolí, někdy krepitací. Místo není zpočátku výrazně bolestivé. $\checkmark$ průběhu hodin dochází k šiření infekce a změně obrazu až do podoby gangrenózní přeměny s hnisavým rozpadem. Popisovaný medián doby prvních symptomů na kưži do gangrenózních změn je 6 dnů (13). S širíící se gangrénou (až na perineum, podbřišek, do oblasti penisu) dochází k septickému stavu pacienta se všemi důsledky celkové toxicity. I přes správnou diagnostiku a okamžitou terapii končí stav často fatálně.

Diagnóza je tedy primárně stanovena na základě anamnestických údajů a fyzikálního vyšetření. Bolestivý otok skrota však může být i u jiných stavů spadajících pod tzv. syndrom akutního skrota (14).

Nejzákladnějším pomocným vyšetřením je laboratorní vyšetření zánětlivých markerů v krvi (krevní obraz, CRP, prokalcitonin, D-dimery, fib- 
Obr. 1. Před výkonem

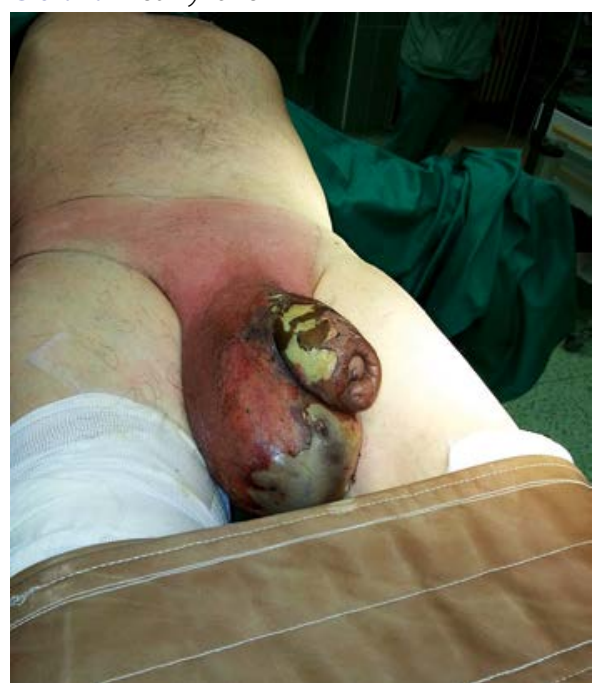

rinogen). Na zvlášt závažný stav ukazuje obraz systémové toxicity se septickými teplotami při neúměrně malém kožním nálezu.

Přežití pacienta je prímo závislé na včasné diagnóze a promptním zahájení léčby. Ta spočívá v okamžitém chirurgickém zákroku zahrnujícím radikální excizi všech gangrenózních i potenciálně postižených okolních tkání (15). Rána se ponechává bez sutury se zavedením drenáže dolních močových cest (epicystostomie) a eventuální odloženou revizí za 24-48 hodin, zvažována má být i derivace stolice (střevní stomie či aktivní odsávání stolice z anorekta) (16). Farmakologická terapie je založena na antibiotické terapii pokrývající celé bakteriální spektrum - např. kombinace cefalosporinu III. generace s aminoglykosidem a metronidazolem, ev. fluorochinolon s metronidazolem, ev. karbapenem s aminoglykosidem. Záleží samozřejmě také na zjištěném pưvodci, při průkazu streptokokové infekce se použivá klindamycin, u enterokokové infekce je základem vankomycin (14). Maximální možná dávka antibiotikje základní podmínkou, samozřejmostí je intenzivní či resuscitační péče podle stavu pacienta.

\section{Kazuistika}

Pacient, 79 let, byl aktuálně hospitalizován pro zhoršení kardiálního selhání (opakovaná hospitalizace) a zhoršenou mobilitu. Z anamnestických údajů: ischemická choroba srdeční a diabetes mellitus II. typu. Rizikovým faktorem byla u pacienta benigní hyperplazie prostaty, vzhledem k celkovému stavu a riziku operace mu byla doporučena permanentní močová drenáž cévkou. Tu však opakovaně odmítnul. Z chronické medikace uvedeno: Glymexan, Siofor, Enalapril, Monosan, Furon, Pentomer 400,
Obr. 2. Po výkonu

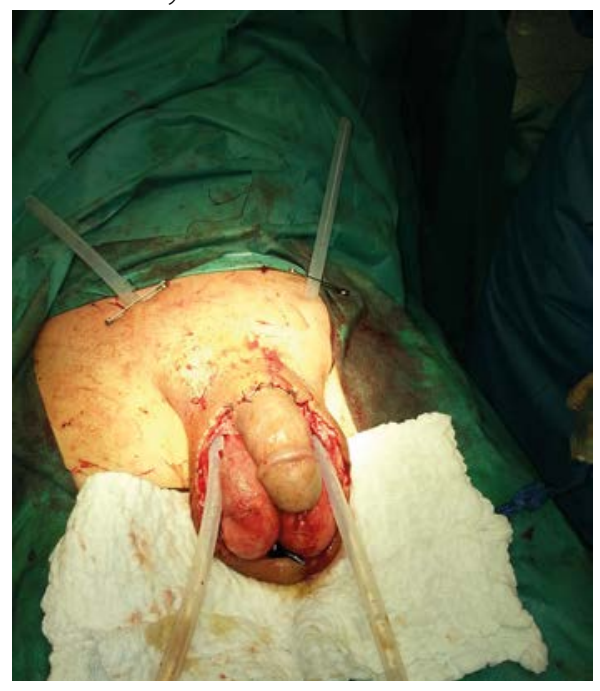

Atrovent sprej. Urologické konzilium bylo voláno v únoru 2014 k zavedení permanentního katétru.

Při príijetí pacient udával bolesti levého třisla, zhoršení mikce negoval. Při fyzikálním vyšetření bez větších odchylek, lokálně pouze nález drobné zarudlé oděrky ventrální plochy penisu. Močový katétr byl zaveden bez obtíží. Chirurgem konstatován lehce zduřelý „odřený penis“, doporučeny koupele $v$ heřmánku. Laboratorní vyšetření při přijetí: leuko 15,7×10/l, HGB $128 \mathrm{~g} / \mathrm{l}$, urea 11 mmol/l, krat. 79 umol/l, CRP 19,1 g/l. Byl nasazen Klacid a od druhého dne pobytu Ciplox p.o. Vzhledem ke zvětšujícímu se otoku skróta bylo opakováno urologické konzilium: otok penisu a pravého hemiskorta s oděrkou na skrótu a ventrální ploše penisu, navrhovanou epicystostomii pacient odmítl. Čtvrtý den pobytu proběhlo chirurgické a urologické konzilium po překladu na chirurgické oddělení nemocnice. Vzhledem k lokálnímu nálezu typickému pro fasciitidu penisu a skróta (obrázek 1) byl pacientovi neprodleně proveden chirurgický výkon: debridement nekrotické kůže a podkoží, cirkumcize, zaveden trubicový drén (obrázek 2) a nově nasazena kombinovaná antibiotická terapie Augmentin, Gentamicin a Metronidazol při mikrobiologickém nálezu Streptococcus beta-hemolyt. skup. A pyogenes.

Dva dny po operaci pacient na následky těžké kardiální dekompenzace upadá do bezvědomí a po úspěšné resuscitaci je přeložen na ARO. Zde je provedena punkční epicystostomie a následně pro pokračující gangrénu v oblasti šourku (obrázek 3) odstraněna kưže celého šourku. Šestý den po primární chirurgické revizi je provedena re-excize s oboustrannou orchiektomií (obrázek 4). Ani tento zákrok však nezastavil šiření gangrény do hlubších vrstev penisu. Celkový velmi špatný

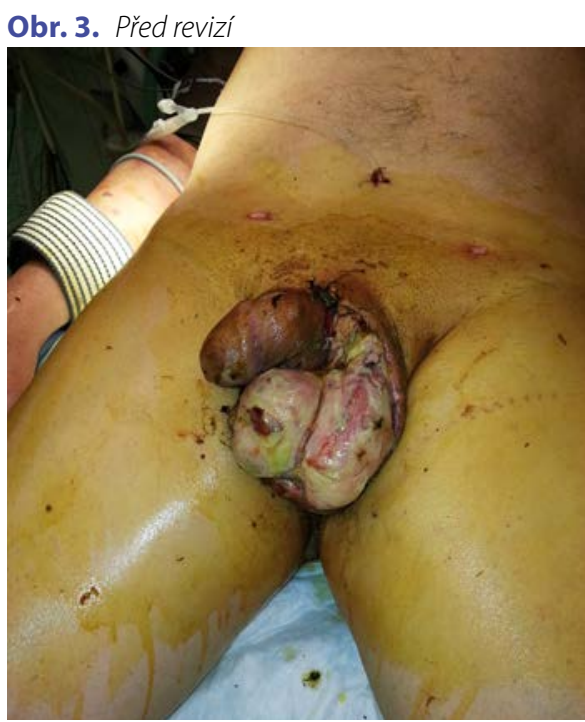

stav pacienta neumožňoval provedení dalších menších operací v celkové narkóze, proto třináctý pooperační den proběhl radikální výkon: nekrektomie, penektomie, perineální uretrostomie (obrázek 5). Mikrobiologicky nebyla zjištěna v moči infekce, stěry z rány byly negativní, v dýchacích cestách zjištěn methicilin rezistentní zlatý stafylokok (MRSA) a kvasinky (candida krusei). Probíhala dále intenzivní péče včetně umělé plicní ventilace, sedace a presorické podpory kombinací katecholaminů (antibiotika a antimykotika: Mycomax, Colomycin, Amikin, Dalacin).

Po těchto výkonech se proces šírení infekce na 10 dnů zastavil, následně ale došlo k opětovnému zhoršení stavu s šírením infekce na oblast podbřišku a oblast třísla a proximální části stehna levé dolní končetiny (obrázek 6). Dle chirurgicko-urologického konzilia nebyl dále stav chirurgicky řešitelný. Laboratorní nálezy: leuko $13,3 \times 10^{9} /$, trombocyty $71 \times 10^{9} /$, CRP $230 \mathrm{~g} / \mathrm{l}$, prokalcitonin 2,8 $\mu \mathrm{g} / \mathrm{l}$, D-dimery $2600 \mathrm{mg} / \mathrm{l}$.

Pacient po dalším týdnu konzervativní terapie pod obrazem multiorgánového selhání při sepsi zemřel. Pitva tuto diagnózu potvrdila. Revidovaný nález biopsie z tkání skrota ještě popsal fibrinoidní nekrózy arterií a jejich trombózy jako velice pravděpodobný důsledek základního onemocnění polyarteritis nodosa. Tedy onemocnění, které pacient dosud neměl diagnostikováno.

\section{Diskuze}

V popisovaném prípadě došlo k rychlé progresi lokálního nálezu a celkových příznaků přes minimální iniciální nález.

Vzhledem k rychlému průběhu uvedeného onemocnění musí být pacientům poskytnuta maximální možná a včasná intenzivní chirurgic- 


\section{Obr. 4. PO OE bill}

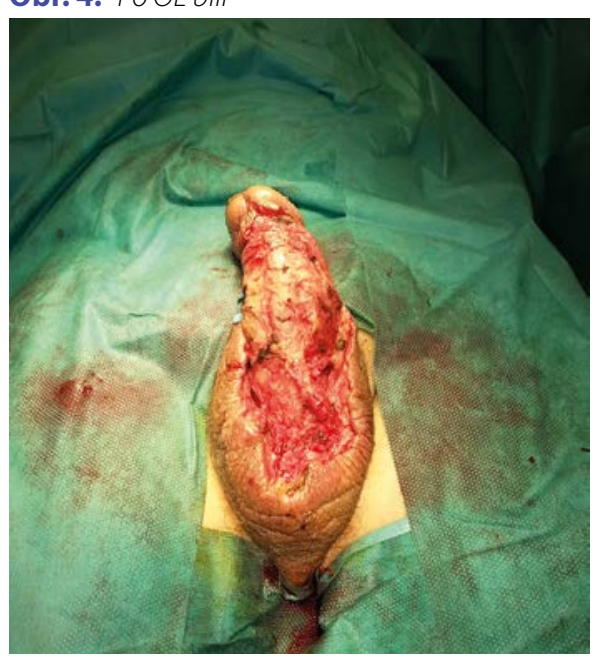

ká a antibiotická léčba (17). Proto je také dưležité stanovit pevná diagnostická a prognostická kritéria, která by mohla neomylně vést k rychlé léčbě. Existují skórovací schémata, která pomáhají diagnosticky, ale i prognosticky - např. Fournier's Gangrene Severity Index (FGSI), Uludag Fournier's Gangrene Severity Index (UFGSI) a Ageadjusted Charlson Comorbidity Index (ACCI). (18-20). Zásadní je určení definitivního rozsahu chirurgického výkonu, mnohdy bývá pro stanovení rozsahu nekrózy prínosnější provedení magnetické rezonance než CT (21). Některé parametry krevní srážlivosti (faktor VIII, lupus antikoagulans, protein C, fibrinogen) mohou být pomocnými diagnostickými parametry pro FG (22).

Jsou také stanovovány různé prognostické parametry: např. ženské pohlaví (23), nízká hladi-

\section{LITERATURA}

1. Eke N. Fournier's gangrene: a review of 1726 cases. $\mathrm{Br} J$ Surg. 2000; 87(6): 718-728

2. Norton KS, Johnson LW, Perry T, et al. Management of Fournier's gangrene: an eleven year retrospective analysis of early recognition, diagnosis, and treatment. Am Surg. 2002; 68(8): 709-713.

3. Stone HH, Martin JD, Jr. Synergistic necrotizing cellulitis. Ann Surg. 1972; 175(5): 702-711.

4. Ersoz F, Sari S, Arikan S, et al. Factors affecting mortality in Fournier's gangrene: experience with fifty-two patients. Singapore Med J. 2012; 53(8): 537-540.

5. Sinha R, Arachchi A, Lee $P$, et al. Fournier gangrene in pregnancy. Obstet Gynecol. 2015; 125(6): 1342-1344.

6. Ho MP, Chou AH, Cheung WK. Fournier's gangrene in an elderly woman. J Am Geriatr Soc. 2014; 62(2): 402-403.

7. Ekingen $\mathrm{G}$, Isken $\mathrm{T}$, Agir $\mathrm{H}$, et al. Fournier's gangrene in childhood: a report of 3 infant patients. J Pediatr Surg. 2008; 43(12): e39-42.

8. Fournier JA. Gangrène-foudroyante de la verge. Semin Med. 1883; 3: 345.

9. Brod'ak M, Romzova M, Kosina J. Urologic surgery in diabetes. Vnitr Lek. 2008; 54(5): 457-463.

10. Riedler I, Primus G, Trummer H, et al. Fournier's gangrene after tension-free vaginal tape (TVT) procedure. Int Urogynecol J Pelvic Floor Dysfunct. 2004; 15(2): 145-146.
Obr. 5. Po radikální penectomii

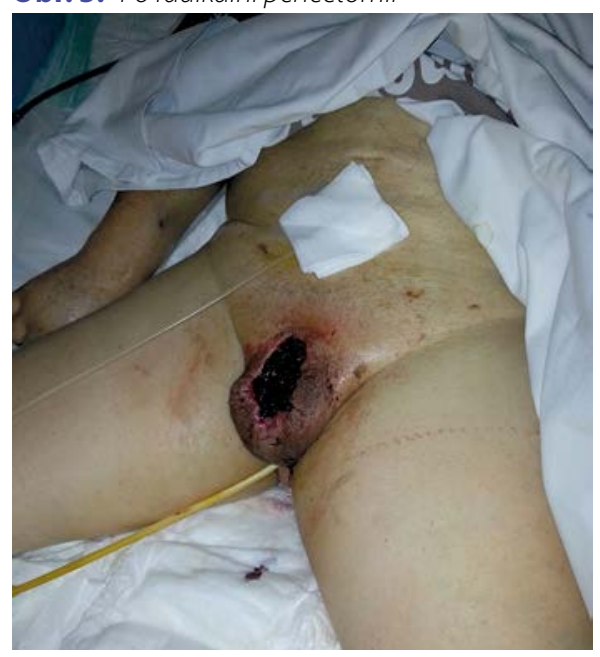

na hořčíku (24), hypertenze a vysoký body mass index (11), chronické renální selhání s nutností hemodialýzy a vysoká hladina leukocytů při vstupním vyšetření a jsou to faktory zhoršující mortalitu u pacientů s FG (4).

V terapii chybou obvykle bývá nastavení nízkých dávek antibiotik z obavy před jejich nežádoucím účinkem. Tato obava bývá lichá, naopak vstupní použití nízkých dávek vystavuje pacienta riziku selhání léčby a úmrtí (14). Derivace moči je optimální ve většině případů punkční epicystostomií. Nutné je pacienta dostatečně hydratovat a doporučuje se aplikace nízkomolekulárních heparinů (25).

$\checkmark$ diferenciální diagnostice je nutno vyloučit jiné přičiny tzv. syndromu akutního skrota. Varlata bývají postižena nekrózou jen výjimečně,
Obr. 6. Progerese infekce na obl. trísla a prox. části stehna LDK

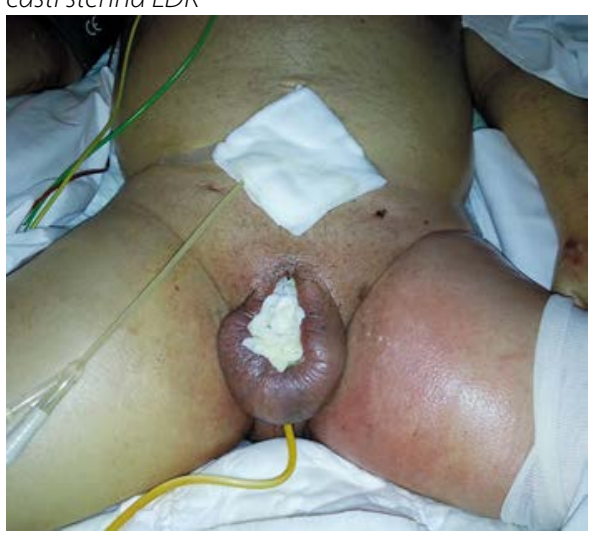

vzhledem k dobrému cévnímu zásobení z aorty (26), stejně tak obvykle nebývá postižena kůže penisu (27).

Hojení rány může velmi příznivě ovlivnit hyperbarická komora a ev. i VAC (Vacuum-assisted closure) systém (28). Pokud pacient přežije akutní fázi onemocnění, opakovaně podstupuje reparační plastické výkony k úpravě kožních a tkáňových defektů.

\section{Závěr}

Fournierova gangréna je závažným urologickým onemocněním. Rychlé stanovení diagnózy, maximální možná antibiotická, chirurgická a komplexní intenzivní péče je předpokladem pro jeho úspěšné zvládnutí. Multioborová spolupráce, i přes výraznou mortalitu, tyto šance zvyšuje.

Autor prohlašuje, že zpracování článku nebylo podpořeno žádnou společností.

11. Tang LM, Su YJ, Lai YC. The evaluation of microbiology and prognosis of fournier's gangrene in past five years. Springerplus. 2015; 4: 14.

12. Crowell W, Roberts R, Tarry S. Fungal Fourniers Gangrene in an Immunocompromised Patient. Urol Case Rep. 2016; 4: 1-3. 13. Altarac S, Katusin D, Crnica S, et al. Fournier's gangrene: etiology and outcome analysis of 41 patients. Urol Int. 2012; 88(3): 289-293. 14. Macek P. Fournierova gangréna. In: Zámečník L, Macek P, et al. Modernífarmakoterapiev urologii. Praha: Maxdorf; 2012. 45-48. 15. Kolombo I, Hanuš T, Porš J, et al. Infekce močových cest pro praktické lékaře a specialisty: Galén; 2007. 281 s.

16. Goh M, Chew MH, Au-Yong PS, et al. Nonsurgical faecal diversion in the management of severe perianal sepsis: a retrospective evaluation of the flexible faecal management system. Singapore Med J. 2014; 55(12): 635-639.

17. El-Shazly M, Aziz M, Aboutaleb H, et al. Management of equivocal (early) Fournier's gangrene. Ther Adv Urol. 2016; 8(5): 297-301. 18. Kincius M, Telksnys T, Trumbeckas D, et al. Evaluation of LRINEC Scale Feasibility for Predicting Outcomes of Fournier Gangrene. Surg Infect (Larchmt). 2016; 17(4): 448-453. 19. Yim SU, Kim SW, Ahn JH, et al. Neutrophil to Lymphocyte and Platelet to Lymphocyte Ratios Are More Effective than the Fournier's Gangrene Severity Index for Predicting Poor Prognosis in Fournier's Gangrene. Surg Infect (Larchmt). 2016; 17(2): 217-223.
20. Tuncel A, Keten T, Aslan Y, et al. Comparison of different scoring systems for outcome prediction in patients with Fournier's gangrene: experience with 50 patients. Scand J Urol. 2014; 48(4): 393-399.

21. Yoneda A, Fujita F, Tokai $H$, et al. MRI can determine the adequate area for debridement in the case of Fournier's gangrene. Int Surg. 2010; 95(1): 76-79.

22. Sahin H, Aflay U, Kilinc N, et al. Coagulation parameters in the patients with Fournier's Gangrene. Int Urol Nephrol. 2005; 37(4): 733-737.

23. Czymek R, Frank P, Limmer S, et al. Fournier's gangrene: is the female gender a risk factor? Langenbecks Arch Surg. 2010; 395(2): 173-180.

24. Erol B, Tuncel A, Tok A, et al. Low magnesium levels an important new prognostic parameter can be overlooked in patients with Fournier's gangrene: a multicentric study. Int Urol Nephrol. 2015; 47(12): 1939-1945.

25. Kolombo I. Fournierova gangréna v současné urologické praxi. Urol pro praxi. 2011; 12(4): 234-237.

26. Quatan N, Kirby RS. Improving outcomes in Fournier's gangrene. BJU Int. 2004; 93(6): 691-692.

27. De S, Belsante MJ, Tausch TJ, et al. A case of Fournier's gangrene necessitating total penectomy. Can J Urol. 2015;22(6): 8108-8111. 28. Pšenčík $L$, Hynčica J. Fournierova gangréna a její možné komplikace. Urol pro praxi. 2014; 15(1): 33-35. 